\title{
E-Learning Competencies for Teachers in Secondary and Higher Education
}

\author{
doi:10.3991/ijet.v4i2.739 \\ V. Awouters, S. Jans \\ Limburg Catholic University College, Diepenbeek, Belgium
}

\begin{abstract}
Teaching and learning with ICT requires specific competencies for teachers and lectures. Too much attention was given to the technological aspects. Teachers learned to work with hard- and software. A typical example is the European Computer Driving License (ECDL). A lot of people attend courses on text processing, spreadsheets... but using a Virtual Learning Environment like e.g. Blackboard or Moodle demands more didactical than technical skills. Especially e-learning and blended learning is too demanding to let teachers learn to use these tools only by experimenting. More and more is generally accepted that the e-learning competencies for teachers require a longer course. Which competences and how these can be realized is the main focus of this paper? Besides the theoretical background, two examples will be showed.
\end{abstract}

Index Terms-digital didactics, e-learning competencies, European Computer Driving License, Information and Communication Technology (ICT), postgraduate e-learning.

\section{THEORETICAL BACKGROUND}

\section{A. Introduction}

When ICT was introduced in schools, teachers often got courses on how to use technology. Still today these kind of courses are successful. The ECDL-foundation even graduates people that prove to have basic knowledge about seven modules, from basic insights in incourse technology over word-processing to the internet and email. A second kind of courses concern the use of virtual learning environments (VLE). Most courses concern about the technical use of the VLE: how to upload documents? How to make quizzes? ... Often it is seen that these kind of courses on the use of the VLE is directed into online learning. Baars (2006) describes the organizational aspects and advantages of this kind of education: education independent from time and distance. Also the advantages to increase communication among students and to help students with disabilities are described. Baars sees 7 bases for education with digital learning means:

- A better cooperation between students,

- Active learning,

- Direct feedback,

- Better and more contact with teachers and peerstudents,

- Possibilities to learn in different ways,

- Contextual learning,

- A larger spread in different ways of teaching and learning.

\section{B. ICT-competencies for teachers}

Until now too little time is spent on didactical courses to learn teachers to use ICT with a learning surplus value. To offer these kind of courses it is necessary to determine what kind of ICT-competencies teachers really need. In the European U-teacher project the competencies of teachers with regard to interaction with themselves, students, colleagues and the neighborhood are combined with eight specific ICT-themes.

Summarized, the ICT-competencies for teachers have three dimensions:

- The teacher knows for what learning activities ICT can be set in (awareness)

- The teacher has the necessary skills for using hardand software (readiness)

- The teacher knows the pedagogical-didactical elements of ICT (e.g. drill and practice programs)

Zwaneveld and Bastiaens (2007) argue that the most categories of ICT-competencies for teachers are too tighten. They see five competences teachers should have when they want to integrate ICT in their teaching practice:

- Individual media-competencies, this includes the basic knowledge and skills for handling the required hard-and software. These media-competencies also include the use of ict-means, like beamer ... in a traditional teaching practice.

- Critical media-competencies, this includes the skills to select critically the media in the learning process of learners. The criteria are educational, human and social.

- A lifelong learning competence, this means that teachers have to be aware of all the new technologies that are developed and can be integrated in the daily teaching and learning practice. We think e.g. at the PDA (Personal Digital Assistant) and iPhone.

- "Supervising learning process"-competencies, this contains that teachers can optimize the learning processes of learners. Communication is a core element in learning. Learners in groups are more and more located at different places and locations. ICT makes it possible to maintain communication between these learners. It is a competence for teachers to know this and have the necessary skills to organize these kinds of communication and manage and enhance the learning process.

- Educational-design competencies, this competence includes to develop in a right way the necessary 
learning materials and didactical activities by means of ICT and new media.

Zwaneveld and Bastiaens argue that ICT-courses should part from these competencies to learn teachers to use ICT and new media in their teaching practice.

\section{PRACTICAL EXAMPLES}

In this section we describe two 'best practices' of courses that try to enhance the ICT-competencies for teachers. The first example is a very specific example, directed to teachers working in secondary education, especially all the courses in the automobile-sector. The second example is a general and more broad example that is developed in our own university and can be used in every secondary education school and university.

\section{A. Autoweb}

\section{http://www.autowebtraining.eu}

Employees in technical firms, like e.g. garages, need more and more courses. Due to the very fast innovation in technology, lifelong learning is a real need for these labour forces. On the other hand are the needed courses very specialized and expensive. Another problem employers in this economical sectors in Western Europe face is the lack of candidates. Also secondary education schools see that the wide interest for these courses is decreasing. One of the factors that causes this problem is that schools don't have enough money for investing in new and high-tech machines and that teachers have too less developed e-learning competencies.

Therefore an Interreg project was submitted and approved for financing. Interreg is an initiative of the European Union meant for the permanent development of the "European Space". The third phase of Interreg is meant for enhancing the economic and social cohesion within the European Union. Partners in this project are secondary education schools, universities and training centers for in-service employees. This project experiments with partners in several languages: Dutch, German and French. The project starts from employees in garages and wants to offer them a continuing course on four modules, like air conditioning, diagnostic, multiplexing and common rail. The modules are developed in three languages. The theoretical elements are offered through elearning, using the virtual learning environment ILIAS. Main goal for the use of an VLE for the theoretical part is to make time free for the practical courses. For pupils in secondary education the developed materials have been adopted to the learning programmes. All partners together have chosen for the practical learning sessions to cooperate with professional learning centers. Not every school has to invest in very expensive equipment. Teachers and pupils get insights into the new way of learning at the workplace and that 'authentic learning' is tried to implement in schools. At this moment we see that teachers really need e-learning courses to get started with the project.

\section{B. Postgraduate e-learning \& digital didactics}

To realize earlier mentioned ICT-competencies for teachers a longer course is needed. Therefore a postgraduate e-learning was set up. The postgraduate elearning is a course, consisting of four modules, spread over two academic years. The four modules are:
- Pedagogical-didactical module,

- Technical module,

- Communication module,

- Project module

Pedagogical Module: In this module learning theories are studied. Special attention is given to the connectivist theory for online learning. According to Siemens (2004), connectivist theory is for the digital age, where individuals learn and work in a networked environment. As a result, we do not have control over what we learn since others in the network continually change information, and that requires new learning, unlearning old information, and/or learning current information (Anderson, 2008), It is necessary for teachers to know how learning can be realized using new technologies as the internet and WEB 2.0-tools. Not only adults, but also the youth is connected through myspace, facebook...

Technical Module: In the technical module teachers are confronted with a lot of new technologies, that can have an impact on learning. Not only virtual learning environments, but also the internet, WEB 2.0 and even mobile devices are studied. Using mobile devices for learning will require some new strategies - smaller chunks of information, shorter modules, efficient searching for learning objects (Harper, 2008).

Communication Module: The third module deals with side-effects that teachers meet when using e-elements in their courses. Examples are the ethical and juridicial effects of using ict in education. Also the teachers' role as an e-moderator is studied.

Project module: In the last module, teachers chose a project, in which they prove they can integrate learning elements of each of the previous modules and show their acquired e-competencies. The results of the project module should show to colleagues and staff that a change in the teaching practice is realized and that the changes have a positive impact on the learning-results of learners.

Other courses: There are more examples of courses, like e.g. Sheffield Hallam University (UK) offers a Master of Science in E-Learning (http://www.shu.ac.uk/educa tion/elmac/). UOC (Spain) offers a European Certificate in E-Learning Course Design and Teaching (http://www.eden-online.org/contents/UOC_info.pdf).

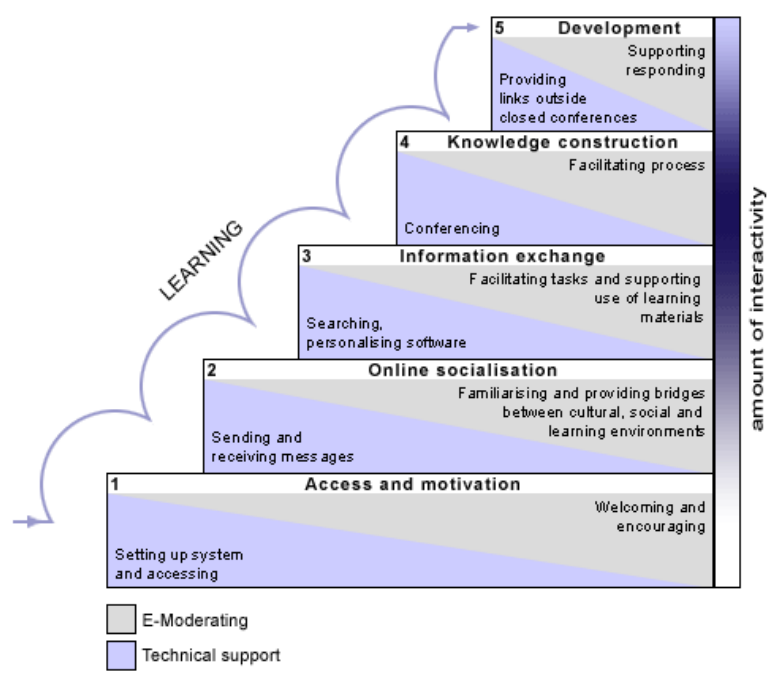

Figure 1. 5 stage model, http://www.atimod.com/etivities/5stage.shtml 
But this is not enough. Teachers who want to change need an innovative environment to act in. Therefore also management has to change. For that reason our institution offers together with the postgraduate e-learning also a postgraduate pedagogical leadership for schoolmanagement-teams. In this postgraduate school-leaders can learn how to deal with innovation and high tech learning environments.

And it doesn't stop with those courses. Also a project, called "Wireless Web Kids" was submitted and is funded by the Flemish Government. In this project PDA's and iPhone's are used to do some learning activities with geocashing with pupils. This triangle (Management - Teacher - Students) is needed to realize e-learning in education.

\section{CONCLUSIONS}

As conclusion can be formulated that realizing elearning competencies with teachers is a multidisciplinary task that takes time. Technology is part of the course, but ICT-competencies for teachers requires much more. Teachers are part of school-live. If ICT-competencies have to be developed and shown in teaching practice, the board of directors have to develop a climate that encourages the high-tech-use in schools. Pupils have to be encouraged to learn using high-tech. Also cooperation with the work floor in companies is necessary. Authentic learning requires to imitate the real life at the workspace as much as possible. E-learning is integrated in real-life, so it also has to be implemented in secondary education schools.

\section{REFERENCES}

[1] Anderson T., The theory and Practice of Online Learning, Second Edition, 2008, AU Press Athabasca University, Edmonton, Canada.

[2] Baars,G.J.A.; Wieland, A.; Van de Ven, M.J.J.M.; Jager, K.M.: Leren (en) doceren met digitale leermiddelen in het hoger onderwijs, 2006, Lemma, Den Haag, Nederland.

[3] Connectivism, http://www.connectivism.ca

[4] ECDL, http://www.ecdl.org/publisher/index.jsp

[5] Harper D., Education for a Digital World, Advice, Guidelines and Effective Practice from Around the Globe, 2008, BCampus and Commonwealth of Learning, Vancouver, Canada.

[6] Hogenbirk, P.: Docenten: Klik 't Professionaliseren voor een ictpraktijk, 2006, Utrecht, Nederland.

[7] Salmon G., E-Tivities, http://www.atimod.com/e-tivities/intro. $\underline{\text { shtml }}$

[8] Sheffield Hallam University, ELMAC, http://www.shu.ac.uk/edu cation/elmac

[9] UOC, http://www.eden-online.org/contents/UOC_info.pdf

[10] U-Teacher, a European project on teachers' professional profile in ICT for education, http://ulearn.itd.ge.cnr.it/uteacher

[11] Zwaneveld B.; Bastiaens T.: Specifieke ICT competencies van docenten, 2007, Onderwijsinnovatie, Open Universiteit Nederland.

\section{AUTHORS}

V. Awouters lecturer \& researcher at Limburg Catholic University College, Teachers Training dept, Agoralaan, gebouw B bus 4, B3590 Diepenbeek Belgium (e-mail: valere.awouters@khlim.be )

S. Jans, lecturer \& researcher at Limburg Catholic University College, Teachers Training dept, Agoralaan, gebouw B bus 4, B3590 Diepenbeek Belgium (e-mail: sebastiaan.jans@khlim.be )

This article was modified from a presentation at the International Conference ICBL2008 in Florianópolis, Brazil, Novemer 2008. Manuscript received 28 November 2008. Published as submitted by the authors. 